Muhammed, A., Rodgers, A. \& Hughes, D. E. (1959). J. gen. Microbiol. 20, $482-495$

\title{
Purification and Properties of a Polymetaphosphatase from Corynebacterium xerosis
}

\author{
By AMIR MUHAMMED, A. RODGERS aNd D. E. HUGHES \\ Medical Research Council Unit for Research in Cell Metabolism, Department \\ of Biochemistry, University of Oxford
}

SUMMARY: An enzyme which splits high molecular weight polymetaphosphate (PMP) to orthophosphate has been extracted from Corynebacterium xerosis, partially purified and some of its properties studied. A method for the preparation of bacterial PMP labelled with ${ }^{32} \mathrm{P}$ is described. The enzyme hydrolyses bacterial or synthetic PMP at the same rate. No formation of short-chain phosphate polymers was detected during the reaction and the enzyme did not attack metaphosphates smaller than hexametaphosphate. It does not transfer phosphate from PMP to ADP to form ATP, nor does it synthesize PMP from orthophosphate (Pi) in the presence of ATP or other nucleotides. All the metal ions tested, including $\mathrm{Mg}^{++}$, inhibited the enzyme. Sodium ethylenediaminetetraacetate (EDTA; $0.2 \mathrm{~mm}$ ) stimulated the rate of reaction; higher concentrations inhibited. The significance of polymetaphosphate and enzymes which split it in micro-organisms is briefly discussed.

Enzymes which split polymetaphosphate (PMP) to orthophosphate (Pi) occur in extracts of a variety of micro-organisms including bacteria, yeasts and moulds (Mann, 1944; Kitasato, 1928). Most of the earlier observations were, however, made with polymetaphosphatases which split metaphosphates of low molecular weight, e.g. trimetaphosphate, tetrametaphosphate and hexametaphosphate. More recently Malmgren (1952) studied the breakdown of very high molecular weight PMP preparations by extracts from Aspergillus niger, Penicillium expansum and some other organisms. By measuring the decrease in viscosity and the amount of orthophosphate formation for 2 days at $\mathrm{pH} 5 \cdot 3$ he concluded that low molecular weight compounds such as tetrametaphosphate and pentametaphosphate were the major end-products. More recently, Kornberg, Kornberg \& Simms (1956) prepared an enzyme from Escherichia coli which could synthesize PMP from adenosine triphosphate (ATP); an unidentified primer was also necessary to initiate the reaction. Kornberg (1957) showed that this enzyme also catalysed the reverse reaction, i.e. synthesis of ATP from PMP and adenosine diphosphate (ADP). A similar enzyme has also been slightly purified from Corynebacterium diphtheriae (Kornberg, 1957). The aim of the present investigation was to purify the polymetaphosphatase (PMP-ase) from C. xerosis and to study some of its properties; a relatively simple assay system has been devised. We were also interested in finding out whether this enzyme catalyses the transfer of orthophosphate (Pi) from PMP to a suitable substrate such as ADP, besides breaking PMP to Pi, and whether PMP could directly phosphorylate other compounds, such as glucose, without the intermediation of the ADP-ATP system. 


\section{METHODS}

Organism. The organism used, Corynebacterium xerosis, was originally National Collection of Type Cultures strain no. 7243. The organism was maintained on agar slopes of the medium used for growth (see below).

Growth of organism. Corynebacterium xerosis was grown in rectangular enamelled metal trays (15 in. $\times 10$ in. $\times 1 \frac{1}{2}$ in.) with tight-fitting lids. The plates were sterilized in an oven at $110-150^{\circ}$ for $3 \mathrm{hr}$. The medium added to each plate had the following composition: Tryptone (Oxo Ltd.) $10 \mathrm{~g}$.; glucose $10 \mathrm{~g}$.; $\mathrm{Na}_{2} \mathrm{HPO}_{4} \cdot 2 \mathrm{H}_{2} \mathrm{O}$ (British Drug Houses Ltd.) 8 g.; $\mathrm{KH}_{2} \mathrm{PO}_{4}$ (B.D.H.) 4 g.; $\mathrm{NaCl}$ (A.R.) 4 g.; yeast extract (Oxo Ltd.) 6 g.; water to $400 \mathrm{ml}$. The $\mathrm{pH}$ of the medium was $6 \cdot 8-7 \cdot 0$. Eight g. of agar-agar (Bacto Difco Co.) were added, the medium sterilized in an Erlenmeyer flask by heating at $10 \mathrm{lb}$./sq.in. for $10 \mathrm{~min}$. and then poured into the sterilized plate. Usually five plates were prepared in this way. The plates were allowed to cool until the agar solidified and the inoculum from agar slopes was spread on the medium with a sterilized stainlesssteel spreader. The plates were incubated at $37^{\circ}$ for $18 \mathrm{hr}$. After this time, the cells had fully developed metachromatic granules and were harvested from the plates with ice cold $0 \cdot 15 \mathrm{M}-\mathrm{NaCl}$; glass beads were used for loosening the organism from the agar. The suspension was passed through glass wool in order to remove lumps of agar, centrifuged in the International refrigerated centrifuge at $1000 \mathrm{~g}$. for $20 \mathrm{~min}$. and the organisms washed twice with cold $0 \cdot 15 \mathrm{M}-\mathrm{NaCl}$. The yield of organism prepared in this way was usually about $10 \mathrm{~g}$ wet wt./plate. The organisms were immediately processed for the extraction of the enzyme or stored in the deep freeze at $-15^{\circ}$.

Preparation of extracts containing enzymes. Organisms (50-60 g.) were made into a thick paste by adding $15 \mathrm{ml}$. cold $0.15 \mathrm{M}-\mathrm{NaCl}$ and crushed in a Hughes (1951) bacterial press with a cylinder of $1 \frac{1}{2}$ in. bore. The crushed material was homogenized with $60 \mathrm{ml}$. cold $0 \cdot 15 \mathrm{M}-\mathrm{NaCl}$ in a Potter type glass homogenizer (Potter \& Elvehjem, 1936). The final suspension, when stained with Albert stain (Mackie \& McCartney, 1945) and examined under the microscope, showed very few intact cells.

Preparation of ${ }^{32} \mathrm{P}$ labelled PMP (PM $\left.{ }^{32} \mathrm{P}\right)$. Bacterial polymetaphosphate. $\mathbf{P M}^{32} \mathbf{P}$ was extracted from Corynebacterium xerosis grown on the medium described above, to which $1 \mathrm{mc}$. of carrier-free ${ }^{32} \mathrm{P}$ orthophosphate (Radiochemical Laboratory, Harwell) was added. The washed organisms were extracted with 5 vol. $10 \%(\mathrm{w} / \mathrm{v})$ trichloroacetic acid (TCA) at room temperature and constantly shaken for $5 \mathrm{hr}$. The extraction of $\mathbf{P M}^{32} \mathrm{P}$ was complete in that time (see Table 1). The suspension was centrifuged, the supernatant fluid neutralized with $\mathrm{NaOH}$ and brought to $\mathrm{pH} 3.5$ by adding $5 \mathrm{M}$-acetate buffer (pH 3.5). $\mathrm{PM}^{32} \mathrm{P}$ was precipitated by the addition of $1 \mathrm{ml}$. saturated $\mathrm{BaCl}_{2}$ solution. The flask was thoroughly shaken and left at $0-2^{\circ}$ overnight. The precipitate was collected by centrifugation and washed twice with acetate buffer ( $\mathrm{pH} \mathrm{3.5)}$ and once with absolute ethanol. It was then treated with Amberlite-IR 120 resin $\left(\mathrm{H}^{+}\right.$form) in order to remove $\mathrm{Ba}^{++}$, neutralized and dialysed against distilled water at $0-2^{\circ}$. The final solution was made up to 
$20 \mathrm{ml}$. giving 25,000 counts $/ \mathrm{min}$. (CPM) and containing $3.5 \mu$ mole $\mathrm{P} / \mathrm{ml}$. Approximately $0.25 \%$ of the ${ }^{32} \mathrm{P}$ added to the growth medium was recovered in $\mathbf{P M}^{32} \mathbf{P}$. The resulting product was very viscous. Mixed with solutions of toluidine blue, it showed metachromasy. The absorption maximum shifted from 625 to $530 \mathrm{~m} \mu$. It was precipitated by albumin in $3.5 \%(\mathrm{w} / \mathrm{v})$ perchloric acid, and did not move on paper chromatography, with various solvents, and could not easily be removed from the anion exchange resins except by hydro-

\section{Table 1. The extraction of PMP from Corynebacterium xerosis by} $10 \%(w / v)$ trichloroacetic acid solution

Organism (20 g. wet wt.) was washed, suspended in 5 vol. of $10 \%(w / v)$ TCA and shaken at room temperature for the times stated. The precipitate was removed by centrifugation and metaphosphate determined in the supernatant fluids as described in the text.

$\begin{array}{cc}\begin{array}{c}\text { Time of } \\ \text { extraction }\end{array} & \begin{array}{c}\text { Metaphosphate } \\ \text { phosphorus in } \\ \text { extract }\end{array} \\ \text { (hr.) } & \text { (mg.) } \\ \mathbf{0 . 5} & 1.8 \\ 1.0 & 3.0 \\ 1.5 & 4.9 \\ 2.5 & 7 \cdot 7 \\ 4.5 & 13.3 \\ 9.0 & 14.1\end{array}$

lysis. The $\mathrm{Ba}^{++}$precipitate conformed to the formula $\left(\mathrm{Ba}\left(\mathrm{PO}_{3}\right)_{2}\right)_{n}$ when analysed for $\mathbf{P}$ and $\mathrm{Ba}^{++}$. All the phosphorus in the preparation was hydrolysed when treated with $\mathrm{N}-\mathrm{HCl}$ at $100^{\circ}$ for $7 \mathrm{~min}$. (We have used the term polymetaphosphate in the usual sense to describe the high molecular weight phosphate polymers of this type, although no details are known about the precise structure.)

In contrast to the findings with yeast (Wiame, 1949; Katchman \& Van Wazer, 1954; Juni, Kamen, Reiner \& Spiegelman, 1948), moulds (Belozersky \& Kulaev, 1957; Krishnan, Damle \& Bajaj, 1957) and certain mycobacteria (Mudd, Yoshida \& Koike, 1958; Winder \& Denneny, 1957) no 'acid-soluble' PMP was detected in Corynebacterium xerosis. When organisms were extracted with $5 \%$ TCA at $0-2^{\circ}$ for $1 \mathrm{hr}$. and the extract was treated with $\mathrm{Ba}^{++}$at $\mathrm{pH} 3 \cdot 5$, no precipitate was formed.

Chemical synthesis of $\boldsymbol{P M}^{\mathbf{3 2} P}$. The method of Pfanstiel \& Iler (1952) as modified by Kornberg (1957) for small-scale preparation was used for preparing synthetic $\mathrm{PM}^{32} \mathrm{P}$. To $2 \mathrm{ml}$. of $\mathrm{M}^{-} \mathrm{KH}_{2} \mathrm{PO}_{4}$ in a platinum crucible $200 \mu \mathrm{c}$. of carrier-free ${ }^{32} \mathrm{Pi}$ was added and the $\mathrm{pH}$ was adjusted to 4.5 by adding $\mathrm{N}-\mathrm{KOH}$. The solution was evaporated gently on a sand bath, $2 \mathrm{ml}$. distilled water added from the sides of the crucible and the solution again evaporated. The crucible was then placed in a muffle furnace, the temperature of the furnace was raised to $770^{\circ}$ over a period of $2 \mathrm{hr}$. and maintained at $770-780^{\circ}$ for $1 \mathrm{hr}$. The crucible was then removed from the furnace and allowed to cool. The residue was washed twice with ice-cold distilled water and then treated with Amberlite-IR $120\left(\mathrm{Na}^{+}\right.$form $)$. The mixture was stirred vigorously for $2 \mathrm{hr}$. at $0-2^{\circ}$. After 
this, the resin was removed by centrifugation and the resulting viscous solution was dialysed against demineralized water at $0-2^{\circ}$ for $24 \mathrm{hr}$. The yield of $\mathbf{P M}^{32} \mathrm{P}$ on the basis of $\mathrm{P}$ content and radioactivity measurements was $50-60 \%$. The product had properties similar to those of bacterial $\mathbf{P M}^{32} \mathbf{P}$.

Chemicals. Adenosine triphosphate (sodium salt) and adenosine diphosphate (ADP) were products of the Schwarz Laboratories, Inc., U.S.A. ADP (Ba salt) was converted into the $\mathrm{Na}^{+}$form by shaking with Amberlite IR-120 $\left(\mathrm{H}^{+}\right.$ form) and neutralized with $\mathrm{NaOH}$. Adenosine-5'-monophosphate (AMP; acid) was a Waldhof Type I product of Zellstoffabrik, Wiesbaden, Germany, and was neutralized before use. Potassium polymetaphosphate, sodium hexametaphosphate, sodium tetrametaphosphate and sodium trimetaphosphate were kindly given by Messrs Albright and Wilson Ltd. Pancreatic ribonuclease, deoxyribonuclease and protamine sulphate were obtained from Messrs Light and Co. Ltd.

As the mol. wt. of PMP was not known, the molarity of PMP solutions is given in terms of orthophosphate $(\mathrm{Pi})$ liberated after hydrolysis with $\mathrm{N}-\mathrm{HCl}$ at $100^{\circ}$ for $7 \mathrm{~min}$. The concentration of hexametaphosphate is expressed similarly for the same reason.

Chemical estimations. Phosphorus was estimated by the method of Berenblum \& Chain (1938). The sample was extracted as usual in isobutanol and the volume made up to $10 \mathrm{ml}$. with ethanol. Before developing the colour with $\mathrm{SnCl}_{2}$ the sample was counted in a GM liquid counter tube (type M6) to estimate ${ }^{32} \mathbf{P}$. A suitable number of counts was taken to ensure a standard error of $\pm 2 \%$.

Barium was estimated gravimetrically as $\mathrm{BaSO}_{4}$, protein by the biuret method (Gornall, Bardawill \& David, 1949) and also by the spectrophotometric method of Kalckar (1947) when the nucleic acid content of the solution was low. Total $\mathbf{N}$ was estimated by the micro-Kjeldahl method.

Measurement of enzyme activity. The assay measured the amount of ${ }^{32} \mathrm{Pi}$ liberated from $\mathrm{PM}^{32} \mathrm{P}$ under standard conditions. In the initial work the assay system contained $0 \cdot 1 \mathrm{ml} . \mathrm{MgCl}_{2}(2 \cdot 0 \mathrm{mM}), 0 \cdot 1 \mathrm{ml}$. 2-amino-2-hydroxymethyl propane-1 :3 diol (tris) + maleate buffer $(0 \cdot 1 \mathrm{M}, \mathrm{pH} 7 \cdot 0), 0 \cdot 1 \mathrm{ml}$. $\mathrm{PM}^{32} \mathrm{P}(0.5 \mu-$ mole, 10,000-20,000 CPM/ $\mu$ mole), enzyme, and water to final volume $0.5 \mathrm{ml}$. This system was later altered by omitting $\mathrm{MgCl}_{2}$ and substituting $0 \cdot 1 \mathrm{ml}$. of sodium ethylenediaminetetra-acetate (EDTA; $1 \mathrm{mM}$ ). The mixture was incubated at $37^{\circ}$ for $20 \mathrm{~min}$. and then $0.5 \mathrm{ml}$. of cold $7 \%(\mathrm{w} / \mathrm{v})$ perchloric acid and $1.0 \mathrm{ml} .0 .1 \%(\mathrm{w} / \mathrm{v})$ bovine serum albumin (Armour) was added. The mixture was stirred and placed on ice for $5 \mathrm{~min}$., centrifuged at $0-2^{\circ}$ at $10,000 \mathrm{~g}$ for 5 min., and a suitable sample of the supernatant fluid taken for extraction of ${ }^{32} \mathrm{Pi}$ by the method of Berenblum \& Chain (1938) and counted. One unit of the enzyme is defined as that amount which catalyses the breakdown of $0.001 \mu$ mole of non-dialysable PMP to orthophosphate in $20 \mathrm{~min}$. at $37^{\circ}$.

Purification of the enzyme. Step I. Nuclease treatment. The crushed organisms gave a very viscous suspension after homogenizing. Before attempting any purification, the suspension was treated with nucleases, which resulted in a decrease in viscosity. To $100 \mathrm{ml}$. of the thick suspension was added approximately 
$1 \mathrm{mg}$. each of ribonuclease and deoxyribonuclease (Light and Co. Ltd.), $20 \mu$ mole- $\mathrm{MgCl}_{2}$ and tris buffer $\left(\mathrm{pH} \mathrm{7 \cdot 0)}\right.$. The suspension was incubated at $37^{\circ}$ for $20 \mathrm{~min}$. with occasional shaking, after which it was immediately cooled in ice and centrifuged in the Spinco Model ' $\mathrm{L}$ ' ultracentrifuge at 50,000 $\mathrm{g}$ for 20 min.; $60-70 \%$ of the activity of original extract was then present in the supernatant fluid. The residue was discarded.

Step II. Ammonium sulphate treatment I. Saturated $\left(\mathrm{NH}_{4}\right)_{2} \mathrm{SO}_{4}$ solution (neutralized with $\mathrm{NaOH}$ ) was added to the supernatant fluid from step I at $0-2^{\circ}$. The $\left(\mathrm{NH}_{4}\right)_{2} \mathrm{SO}_{4}$ addition was done with constant mechanical stirring until a final concentration of $60 \%$ saturation was reached. The mixture was kept in ice for $10 \mathrm{~min}$. and centrifuged at $0-5^{\circ}$ in the International refrigerated centrifuge. The supernatant fluid, which was inactive, was discarded and the bulk of the activity was recovered in the residue which was dissolved in tris + maleate buffer ( $\mathrm{pH} \mathrm{7 \cdot 0)}$ to give a final volume of $23 \mathrm{ml}$.

Table 2. Summary of the enzyme-purification procedure

Step no.

1. Nuclease-treated crushed organisms $50,000 \mathrm{~g}$ supernatant fluid

2. $\left(\mathrm{NH}_{4}\right)_{2} \mathrm{SO}_{4} \mathrm{I}$

3. Protamine sulphate $\left(\mathrm{NH}_{4}\right)_{2} \mathrm{SO}_{4} \mathrm{II}$

4. $\left(\mathrm{NH}_{4}\right)_{2} \mathrm{SO}_{4} \mathrm{III}$

5. Ethanol

$\begin{array}{cccccc}\begin{array}{c}\text { Volume } \\ \text { (ml.) }\end{array} & \begin{array}{c}\text { Enzyme } \\ \text { activity } \\ \text { (units/ml.) }\end{array} & \begin{array}{c}\text { Protein } \\ \text { concn. } \\ \text { (mg./ml.) }\end{array} & \begin{array}{c}\text { Total } \\ \text { activity } \\ \text { (units) }\end{array} & \begin{array}{c}\text { Total } \\ \text { protein } \\ \text { (mg.) }\end{array} & \begin{array}{c}\text { Specific } \\ \text { activity } \\ \text { (units/mg. } \\ \text { protein) }\end{array} \\ 90 & 1260 & 42 \cdot 20 & 113,400 & \mathbf{3 7 9 8} & 29 \\ 75 & 1080 & 20 \cdot 10 & 81,000 & 1507 & 54 \\ 23 & 3360 & 40 \cdot 90 & 77,280 & 941 & \mathbf{8 2} \\ 28 & 2560 & 4 \cdot 90 & 71,680 & 137 & 522 \\ 25 & 2344 & 2 \cdot 02 & 58,600 & 51 & 1132 \\ 20 & 1073 & 0 \cdot 38 & 21,460 & 7 \cdot 6 & 2823\end{array}$

Step III. Protamine sulphate treatment. Protamine sulphate solution (20 mg./ml.; pH 5.0) was slowly added to the solution from step II in the cold and with constant stirring. The precipitate was centrifuged off and the supernatant fluid examined for absorption at 260 and $280 \mathrm{~m} \mu$. The addition of protamine sulphate was continued until the $\mathrm{E} 280 / \mathrm{E} 260$ ratio was more than $\mathbf{0 . 7 5}$, the reason being that at ratios higher than this the amount of nucleic acid remaining in the supernatant fluid was very small and did not interfere with further fractionation. A total of $15 \mathrm{ml}$. of the solution of protamine sulphate (equiv. $300 \mathrm{mg}$.) was added and the precipitate was removed by centrifugation. The supernatant fluid was diluted with cold distilled water to $400 \mathrm{ml}$. with constant stirring, and the bulky precipitate formed was centrifuged off and discarded. To the supernatant fluid was added $152 \mathrm{~g}$. solid $\left(\mathrm{NH}_{4}\right)_{2} \mathrm{SO}_{4}$ and the precipitate was collected and dissolved in $20 \mathrm{ml}$. water $\left(\left(\mathrm{NH}_{4}\right)_{2} \mathrm{SO}_{4}(\mathrm{II})\right)$. About $90-95 \%$ of the activity from step II was present in the final solution.

Step IV. $\left(\mathrm{NH}_{4}\right)_{2} \mathrm{SO}_{4}$ fractionation III. The above solution was subjected to $\left(\mathrm{NH}_{4}\right)_{2} \mathrm{SO}_{4}$ fractionation. Saturated $\left(\mathrm{NH}_{4}\right)_{2} \mathrm{SO}_{4}$ solution was added to give a saturation of $28 \%$ and the precipitate was centrifuged off and discarded. Saturated $\left(\mathrm{NH}_{4}\right)_{2} \mathrm{SO}_{4}$ was added to the supernatant fluid to bring the con- 
centration to $54 \%$ and the precipitate which formed was collected and redissolved in $25 \mathrm{ml}$. water $\left(\left(\mathrm{NH}_{4}\right)_{2} \mathrm{SO}_{4}(\mathrm{III})\right)$.

Step $V$. Ethanol fractionation. The $\left(\mathrm{NH}_{4}\right)_{2} \mathrm{SO}_{4}$ (III) fraction was further purified by reprecipitation with absolute ethanol at $-15^{\circ}$. The fractionation was carried out in a salt ice bath maintained at $-15 \pm 1^{\circ}$, and the fractions were collected in the refrigerated centrifuge at $-15^{\circ}$. The fraction appearing between 60 and $75 \%(\mathrm{v} / \mathrm{v})$ ethanol in water contained most of the activity and was collected. Active material was extracted with tris buffer ( $\mathrm{pH} 7 \cdot 0)$. In some experiments, where concentrated enzyme preparation was required, the final solution was brought to a $50 \%$ saturation with $\left(\mathrm{NH}_{4}\right)_{2} \mathrm{SO}_{4}$ and the residue dissolved in a small amount of water without loss of activity. The enzyme preparation thus obtained was dialysed against $0 \cdot 1 \mathrm{M}-\left(\mathrm{NH}_{4}\right)_{2} \mathrm{SO}_{4}$ at $\mathrm{pH} 7 \cdot 0$ and $\mathbf{0}-\mathbf{2}^{\circ}$ for $24 \mathrm{hr}$. The overall purification, on a protein basis, was approximately 100 times.

\section{RESULTS}

Specificity. The purified enzyme did not hydrolyse trimetaphosphate, tetrametaphosphate, pyrophosphate, ATP or glucose-6-phosphate. Hexametaphosphate (Graham's salt) was broken down almost as rapidly as PMP. Bacterial PMP was hydrolysed as rapidly as the synthetic PMP (Table 3).

Table 3. Action of PMP-ase on various substrates

The reaction mixture consisted of $\mathrm{MgCl}_{2}$ solution $0 \cdot 1 \mathrm{ml} .(0 \cdot 2 \mu \mathrm{mole})$; tris + maleate buffer (pH 7.0) $0.1 \mathrm{ml}$; ; enzyme solution $0.1 \mathrm{ml}$. (780 units); substrate solution, $0.1 \mathrm{ml}$.; water, $0.1 \mathrm{ml}$. The mixture was incubated at $37^{\circ}$ for $20 \mathrm{~min}$. and the reaction stopped by adding $0.5 \mathrm{ml} .7 \%(\mathrm{w} / \mathrm{v})$ perchloric acid. The mixture was centrifuged and orthophosphate (Pi) estimated in the supernatant fluid by the method of Berenblum \& Chain (1938). A blank was run for the enzyme and for each substrate.

\begin{tabular}{|c|c|c|c|c|c|}
\hline \multirow[b]{3}{*}{ Substrate } & \multicolumn{2}{|c|}{ Amount added } & & & \\
\hline & \multirow{2}{*}{$\begin{array}{c}\text { Substrate } \\
(\mu \text { mole })\end{array}$} & \multirow{2}{*}{$\begin{array}{c}\text { Total Pi in } \\
\text { substrate } \\
(\mu \text { mole P) }\end{array}$} & \multicolumn{3}{|c|}{ Pi formed ( $\mu$ mole $)$} \\
\hline & & & Observed & Blank & Net \\
\hline Trimetaphosphate & $0 \cdot 5$ & $1 \cdot 5$ & $0 \cdot 14$ & $0 \cdot 14$ & $\mathbf{0}$ \\
\hline Tetrametaphosphate & $0 \cdot 5$ & $2 \cdot 0$ & $0 \cdot 14$ & $0 \cdot 14$ & $\mathbf{0}$ \\
\hline Pyrophosphate & $1 \cdot 00$ & $\mathbf{2} \cdot \mathbf{0}$ & $0 \cdot 22$ & $0 \cdot 23$ & 0 \\
\hline ATP & $1 \cdot 00$ & $\mathbf{3} \cdot \mathbf{0}$ & $\mathbf{0} \cdot \mathbf{2 5}$ & $\mathbf{0 . 2 6}$ & 0 \\
\hline Glucose-6- $\mathrm{PO}_{4}$ & $0 \cdot 50$ & 0.5 & $0 \cdot 08$ & 0.08 & 0 \\
\hline Hexametaphosphate & - & 1.58 & $1 \cdot 29$ & 0.46 & 0.83 \\
\hline Polymetaphosphate (synthetic) & - & 1.01 & 0.86 & 0.08 & 0.78 \\
\hline Polymetaphosphate (bacterial) & 一 & $0 \cdot 05$ & $0 \cdot 46$ & $0 \cdot 07$ & $0 \cdot 39$ \\
\hline
\end{tabular}

Addition of ATP, ADP or AMP to the complete reaction mixture did not significantly affect the breakdown of PMP to orthophosphate (Table 4). When ADP, glucose and hexokinase were added, there was no decrease in the counts appearing in the orthophosphate fraction and no incorporation into the acid stable $\mathbf{P}$ fraction. This clearly indicates that the enzyme is not capable of transferring phosphate from PMP to ADP or AMP (cf. Kornberg, 1957). 
Table 4. Effect of adenine nucleotides on PMP-ase activity

The reaction mixture consisted as usual of tris buffer, $\mathbf{M g}^{++}, \mathbf{P M}^{32} \mathbf{P}$ and enzyme solution. Following additions were made and enzyme activity measured as usual.

\begin{tabular}{|c|c|c|}
\hline Addition & $\begin{array}{l}\text { Final concn. } \\
\quad(\mathrm{mM})\end{array}$ & $\begin{array}{l}\text { Counts/min. } \\
\text { in }{ }^{32} \mathbf{P i}\end{array}$ \\
\hline None & - & 3491 \\
\hline ATP & $2 \cdot 0$ & 3532 \\
\hline ADP & 4.0 & 3505 \\
\hline AMP & $2 \cdot 0$ & 3545 \\
\hline Glucose & $10 \cdot 0$ & \\
\hline ADP & $2 \cdot 0$ & 3502 \\
\hline Hexokinase J & $0.05 \mathrm{mg}$. protein & \\
\hline
\end{tabular}

\section{Kinetics of the enzyme}

$\mathrm{pH}$ effect and stability. The $\mathrm{pH}$ dependence of the enzyme was studied in $0 \cdot 1 \mathrm{~m}$-tris + maleate buffer at $\mathrm{pH}$ 5-8. The optimum $\mathrm{pH}$ value was at $\mathrm{pH} 7 \cdot 0$ and there was very little activity at $\mathrm{pH} 6 \cdot 0$ (Fig. 1). The enzyme was completely

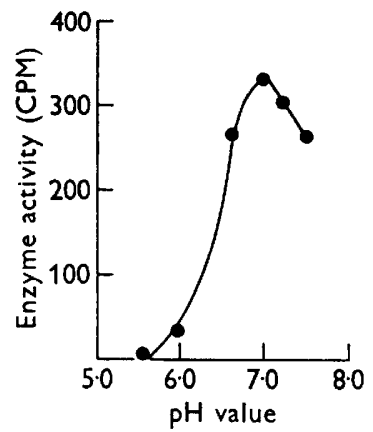

Fig. 1

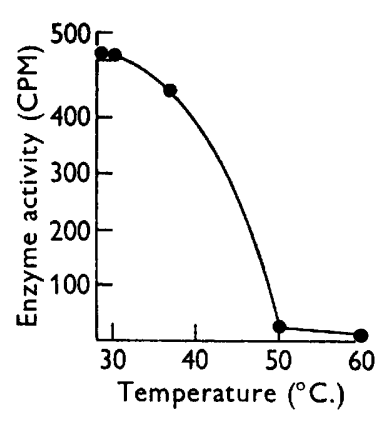

Fig. 2

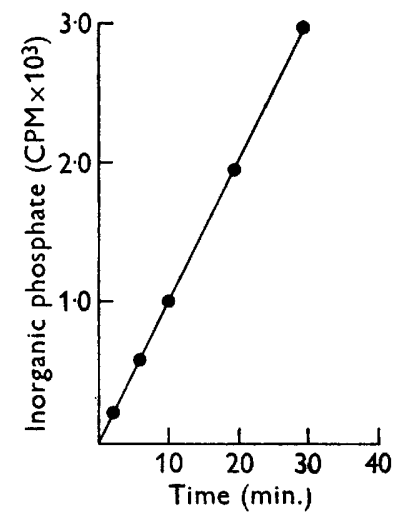

Fig. 3

Fig. 1. Effect of $\mathrm{pH}$ value on enzyme activity. The reaction mixture contained purified dilute enzyme 50 units; $\mathbf{P M}^{32} \mathbf{P}, 0.5 \mu$ mole-P; $\mathbf{M g C l}_{2}, 0.2 \mu$ mole; tris + maleate buffer $(10 \mu$ mole); water to $0.5 \mathrm{ml}$. Enzyme activity was measured as usual after $20 \mathrm{~min}$. incubation at $37^{\circ}$.

Fig. 2. Effect of temperature on enzyme activity. Assay mixture contained: purified enzyme 200 units ; $\mathrm{PM}^{32} \mathrm{P}, 0.5 \mu$ mole ; tris + maleate buffer (pH 7.0), $10 \mu$ mole; $\mathrm{MgCl}_{2}, 0.2 \mu \mathrm{mole}$; water to $0.5 \mathrm{ml}$. Before adding to the assay system the enzyme preparation was first incubated for $20 \mathrm{~min}$. at the different temperatures and then assayed for activity as usual.

Fig. 3. Rate of enzyme reaction with time. The reaction mixture contained: purified enzyme 320 units; $\mathrm{PM}^{32} \mathrm{P}, 0.5 \mu$ mole; tris + maleate buffer (pH 7.0), $10 \mu$ mole; $\mathrm{MgCl}_{2}, 0.2 \mu \mathrm{mole}$; water to $0.5 \mathrm{ml}$. Reaction was stopped after different intervals of time and activity measured as usual.

inactivated by incubation at $50^{\circ}$ for $20 \mathrm{~min}$. Incubation at $37^{\circ}$ for $20 \mathrm{~min}$. resulted in a $10 \%$ loss in activity as compared with the activity at $0^{\circ}$ (Fig. 2). There was no loss in activity when the purified enzyme was stored at $-15^{\circ}$ from 5 to 6 weeks. 
Effect of substrate concentration and rate of reaction. The progress of the reaction was proportional with time during a $30 \mathrm{~min}$. period (Fig. 3). The rate of reaction increased approximately linearly with low substrate concentrations up to a final concentration of $0.30 \mathrm{~mm}$ (Fig. $4 a$ ). Further increase in substrate concentration did not increase the rate of orthophosphate formation linearly. The $K m$ value for the PMP-ase as determined from the Burk-Lineweaver plot is $7 \cdot 7 \times 10^{-4} \mathrm{M}$ (Fig. $4 a, b$ ), the molarity being expressed as inorganic orthophosphate added as PMP.

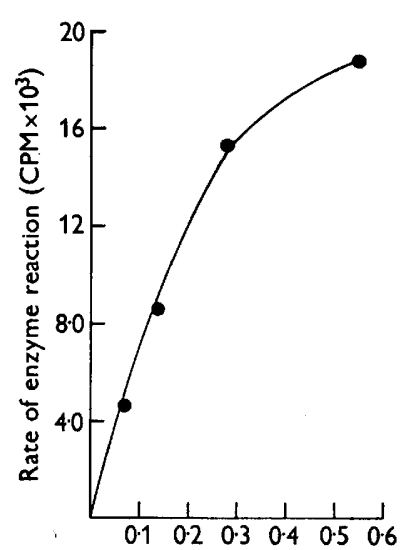

Substrate concentration ( $\mathrm{mM}$ )

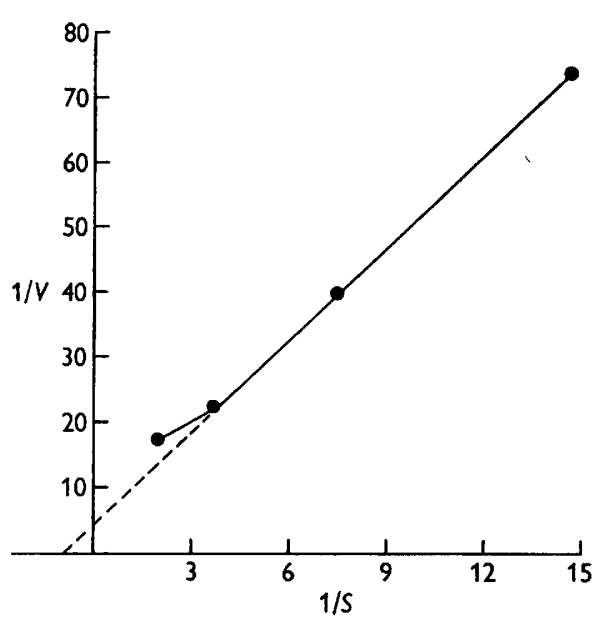

/S

Fig. 4a,b. Initial rate of reaction at different substrate concentrations. The reaction mixture contained : purified enzyme previously dialysed against EDTA, 80 units; tris + maleate buffer ( $\mathrm{pH} 7 \cdot 0$ ), $10 \mu$ mole; EDTA, $0.2 \mu$ mole; different amounts of PM ${ }^{22} \mathrm{P}$; water to $0.5 \mathrm{ml}$. Enzyme activity was measured as usual after $20 \mathrm{~min}$. incubation at $37^{\circ}$. The data is plotted according to Lineweaver $\&$ Burk (1934) in $b$.

When ${ }^{32} \mathrm{Pi}$ was incubated in the presence of ATP instead of $\mathbf{P M}^{32} \mathrm{P}$, all the radioactivity was recovered in the acid soluble inorganic phosphate fraction. As such, no $\mathrm{PM}^{32} \mathrm{P}$ was synthesized and the reaction was not reversible under these conditions.

Effect of metal ions and EDT A on PMP-ase activity. The effect of metal ions, EDTA and some inhibitors on the purified enzyme is shown in Table 5. EDTA stimulated the enzyme appreciably at a final concentration of $0.5 \mathrm{~mm}$. Ammonium molybdate and ammonium vanadate had a slightly stimulatory effect. All the other metal ions tried, namely $\mathrm{Mg}^{++}, \mathrm{Ca}^{++}, \mathrm{Fe}^{++}, \mathrm{Mn}^{++}, \mathrm{Co}^{++}$, $\mathrm{Zn}^{++}$and $\mathrm{Cu}^{++}$inhibited the enzyme to different extents. Uranyl acetate $(0.1 \mathrm{mu})$ almost completely inhibited the polymetaphosphatase activity.

Dialysis against water, tris buffer $(0 \cdot 1 \mathrm{M})$, pyrophosphate buffer $(0 \cdot 1 \mathrm{M})$ or EDTA $(0.02-0.05 \mathrm{M})$ at $\mathrm{pH} 7 \cdot 0$ and $0-2^{\circ}$ completely inactivated the enzyme. Dialysis against $0 \cdot 1 \mathrm{M}-\left(\mathrm{NH}_{4}\right)_{2} \mathrm{SO}_{4}$ under the above conditions did not affect the enzyme activity. In an attempt to remove metal ions the enzyme was dialysed, with continuous stirring, against $0 \cdot 1 \mathrm{M}-\left(\mathrm{NH}_{4}\right)_{2} \mathrm{SO}_{4}+50 \mathrm{~mm}-\mathrm{EDTA}(\mathrm{pH} \mathrm{7} \cdot 0)$ and 0-2 ${ }^{\circ}$ for $24 \mathrm{hr}$. EDTA was removed by dialysis against $0 \cdot 1 \mathrm{M}-\left(\mathrm{NH}_{4}\right)_{2} \mathrm{SO}_{4}$ for $40 \mathrm{hr}$. The effect of different concentrations of $\mathrm{Mg}^{++}$and EDTA was tried on 
Table 5. Effect of metal ions and inhibitors on the PMP-ase activity

The reaction mixture contained: tris + maleate buffer $(\mathrm{pH} 7 \cdot 0) 0.1 \mathrm{ml}$.; purified enzyme solution 0.1 ml.; PM ${ }^{32} \mathrm{P}, 0 \cdot 1 \mathrm{ml}$; other additions as shown below.

\begin{tabular}{|c|c|c|}
\hline \multicolumn{2}{|c|}{ Addition } & \multirow[b]{2}{*}{$\begin{array}{l}\text { Counts/min. in } \\
\text { Pi fraction }\end{array}$} \\
\hline Substance & $\begin{array}{c}\text { Final } \\
\text { concentration } \\
(\mathrm{mM})\end{array}$ & \\
\hline No addition & - & 3102 \\
\hline EDTA & 0.4 & 3807 \\
\hline Ammonium molybdate & 0.4 & 3422 \\
\hline Ammonium vanadate & $0 \cdot 1$ & 3218 \\
\hline $\mathrm{MnCl}_{2}$ & 0.58 & 2737 \\
\hline $\mathrm{FeSO}_{4}$ & 0.55 & 2722 \\
\hline $\mathrm{CuCl}_{2}{ }^{2}$ & $0 \cdot 58$ & 2642 \\
\hline $\mathrm{MgCl}_{2}$ & $0 \cdot 4$ & 2516 \\
\hline $\mathrm{CaCl}_{2}$ & $0 \cdot 4$ & 2232 \\
\hline $\mathrm{ZnCl}_{2}$ & $0 \cdot 4$ & 1123 \\
\hline $\mathrm{Co}\left(\mathrm{NO}_{2}\right)_{2}$ & $0 \cdot 4$ & 609 \\
\hline Uranyl acetate & $0 \cdot 1$ & 151 \\
\hline Sodium arsenate & $1 \cdot 00$ & $\mathbf{3 1 5 2}$ \\
\hline
\end{tabular}

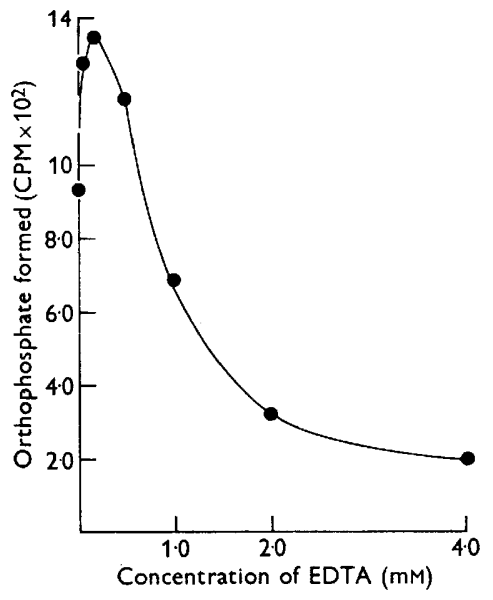

Fig 5

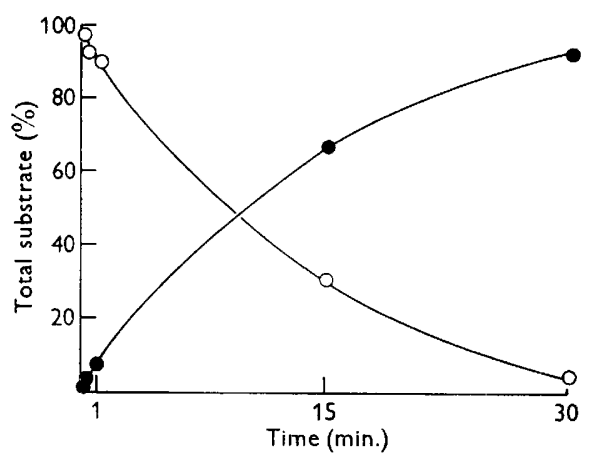

Fig. 6

Fig. 5. The effect of EDTA on the activity of purified enzyme. The reaction mixture contained : purified enzyme previously dialysed against EDTA 105 units; PM $^{32} P, 0.5 \mu$ mole; tris + maleate buffer (pH 7.0), $10 \mu$ mole; different concentrations of EDTA; water to $0.5 \mathrm{ml}$. Enzyme activity was measured as described in the text.

Fig. 6. The release of orthophosphate by PMP-ase action on PM $^{32} \mathrm{P}$ compared to nondialysable $\mathbf{P M}^{32} \mathbf{P}$ remaining. Composition of the reaction mixture was as given in the text (p. 491).

the enzyme preparation dialysed in this way. It was clear (Table 6) that EDTA at low concentration stimulated the enzyme, whereas when the concentration was increased, EDTA had an inhibitory effect (Fig. 5). $\mathbf{M g}^{++}$inhibited the purified enzyme even at low concentrations. When EDTA was added in concentrations sufficient to complex added metals it annulled their inhibitory effects. 


\section{Mechanism of PMP-ase action}

Estimation of orthophosphate and non-dialysable radioactivity in the reaction mixture. Seven tubes were set up as follows: $\mathrm{MgCl}_{2} 0.1 \mathrm{ml} .(0.2 \mu \mathrm{mole})$; trismaleate buffer $0 \cdot 1 \mathrm{ml} .\left(0 \cdot 1 \mathrm{M}, \mathrm{pH} \mathrm{7.0)}\right.$; $\mathrm{PM}^{32} \mathrm{P}, 0 \cdot 1 \mathrm{ml}$. (3062 CPM); purified enzyme $0 \cdot 1 \mathrm{ml}$. (600 units); water, $0 \cdot 1 \mathrm{ml}$. The reaction was stopped after suitable intervals by adding $0.5 \mathrm{ml}$. cold $7 \%(\mathrm{w} / \mathrm{v})$ perchloric acid, the mixture

Table 6. Effect of different concentrations of EDT $A$ and $\mathrm{Mg}^{++}$on

$$
P M P \text {-ase activity }
$$

The reaction mixture contained: tris + maleate buffer (pH 7.0) $0 \cdot 1 \mathrm{ml}$; purified enzyme solution, 0.1 ml.; PM ${ }^{32}$ P, $0 \cdot 1 \mathrm{ml}$; and varying amounts of EDTA or $\mathrm{Mg}^{++}$as shown below.

$\begin{array}{lcc}\text { Addition } & \\ \text { Substance } & \begin{array}{c}\text { Final } \\ \text { concentration } \\ (\text { mM })\end{array} & \begin{array}{c}\text { Counts/min. in } \\ \text { Pi fraction }\end{array} \\ \text { None } & - & 940 \\ \text { EDTA } & 0 \cdot 05 & 1287 \\ \text { EDTA } & 0 \cdot 20 & 1350 \\ \text { EDTA } & 0 \cdot 50 & 1175 \\ \text { EDTA } & 1 \cdot 00 & 684 \\ \text { EDTA } & 2 \cdot 00 & 326 \\ \text { EDTA } & 4 \cdot 00 & 199 \\ \text { Mg }{ }^{++} & 0 \cdot 05 & 802 \\ \text { Mg } & 0 \cdot 20 & 613 \\ \text { Mg } & & 425 \\ \text { Mg }^{++} & 0 \cdot 50 & 307\end{array}$

Table 7. The amounts of ${ }^{32} \mathrm{Pi}$ formed and non-dialysable radioactive material (as counts) left after PMP-ase action for different times

Composition of the reaction mixture as given in the text.

\begin{tabular}{|c|c|c|c|c|c|c|}
\hline \multirow{3}{*}{$\begin{array}{l}\text { Period of } \\
\text { incubation } \\
\text { (min.) }\end{array}$} & \multirow{2}{*}{\multicolumn{2}{|c|}{$\begin{array}{l}\text { a. Counts in Pi fraction } \\
\text { (calculated in the total } \\
\text { reaction mixture) } \\
\text { (CPM) }\end{array}$}} & \multirow{2}{*}{\multicolumn{2}{|c|}{ b. Counts after dialyses }} & \multicolumn{2}{|c|}{ Recovery } \\
\hline & & & & & Total & $\%$ of total \\
\hline & Observed & $\begin{array}{l}\% \text { of total } \\
\text { in } \mathbf{P M}^{\mathbf{3 2}} \mathbf{P}\end{array}$ & Observed & $\begin{array}{l}\% \text { of total } \\
\text { in } \mathbf{P M}^{\mathbf{3 2}} \mathbf{P}\end{array}$ & $\begin{array}{l}\text { CPM } \\
(a+b)\end{array}$ & $\begin{array}{l}\text { counts in } \\
\text { PM }^{32} \mathbf{P} \text { taken }\end{array}$ \\
\hline $\mathbf{0}$ & 60 & $\mathbf{1 . 9}$ & 2939 & $95 \cdot 9$ & 2999 & $97 \cdot 9$ \\
\hline 0.25 & 115 & $3 \cdot 7$ & 2830 & $92 \cdot 4$ & 2945 & $96 \cdot 1$ \\
\hline 1 & 240 & $7 \cdot 8$ & 2737 & $89 \cdot 4$ & 2977 & $97 \cdot 2$ \\
\hline 15 & 2032 & $66 \cdot 8$ & 942 & 30.9 & 2972 & $97 \cdot 2$ \\
\hline 30 & 2832 & $92 \cdot 1$ & 128 & $4 \cdot 1$ & 2951 & $96 \cdot 2$ \\
\hline 60 & 3053 & 99.7 & 16 & 0.5 & 3069 & $100 \cdot 2$ \\
\hline 300 & 3070 & $100 \cdot 2$ & 0 & 0 & 3070 & $100 \cdot 2$ \\
\hline
\end{tabular}

centrifuged and the clear supernatant fluid taken in another tube kept in ice. A sample (0.4 ml.) of the supernatant fluid was taken for ${ }^{32} \mathrm{Pi}$ estimation and another sample $(0.25 \mathrm{ml}$.) for dialysis. The samples were dialysed overnight in $15 \mathrm{l}$. of demineralized water at $0-2^{\circ}$ and the radioactivity remaining in the nondialysable solution was counted. The results are given in Table 7 and Fig. 6. 
It is clear from the results of the above experiment that when PMP was broken down no dialysable intermediates other than $\mathrm{Pi}$ were formed. Very little PMP was left after incubation for $1 \mathrm{hr}$. and almost all of it was recovered as Pi.

Chromatography of the reaction mixture. To confirm the conclusion of the above experiment, the reaction mixtures after different intervals of time were chromatographed. Five tubes were assembled as shown in Table 8 . The reaction was stopped by adding $0.1 \mathrm{ml}$. cold $21 \%(\mathrm{w} / \mathrm{v})$ perchloric acid and the mixture centrifuged. A sample of the supernatant fluid $(0 \cdot 1 \mathrm{ml}$.) was spotted on Whatman no. 4 filter-paper for ascending chromatography as described by Berg (1958). Trimetaphosphate, tetrametaphosphate, PMP and Pi were run as markers. The composition of the solvent was methanol $50 \mathrm{ml}$., $n$-butanol $10 \mathrm{ml}$., water $22 \mathrm{ml}$., aqueous concentrated ammonia (sp.gr. 0.880 ) $18 \mathrm{ml}$., titrated with $25 \%$ (w/v) formic acid to $\mathrm{pH} 11 \cdot 4$. The solvent was run for $16 \mathrm{hr}$. at room temperature, dried and sprayed with Hanes \& Isherwood phosphate spray reagent (Hanes \& Isherwood, 1949). The spot with the same $R_{f}$ value as tetrametaphosphate was present in the enzyme blank and samples 3-5, and did not have any radioactivity. This spot was light blue as compared to the phosphate spots (including tetrametaphosphate) which were dark blue. The spot did not contain any phosphorus, as determined by the method of Berenblum \& Chain (1938) after ashing, and has not yet been identified.

\section{Table 8. Chromatography of the reaction mixtures}

The tubes had $\mathrm{MgCl}_{2}$ solution, $0 \cdot 1 \mathrm{ml}$. (0.2 $\mu$ mole); tris + maleate buffer $(\mathrm{pH} 7 \cdot 0), 0 \cdot 1 \mathrm{ml}$., $\mathrm{PM}^{32} \mathrm{P}, 0.1 \mathrm{ml}$. (2980 CPM, none in No. 1); enzyme solution, $0.1 \mathrm{ml}$. (none in no. 2); water to $0.5 \mathrm{ml}$. total volume. Details of chromatography are given in the text.

\begin{tabular}{|c|c|c|c|c|}
\hline Description & $\begin{array}{c}\text { Period of } \\
\text { incubation } \\
\text { (min.) }\end{array}$ & $\begin{array}{c}\text { Counts at } \\
\text { origin }\end{array}$ & $\begin{array}{c}\text { Counts in } \\
\text { Pi spot }\end{array}$ & Total \\
\hline Without PM ${ }^{32} \mathbf{P}$ & $\mathbf{5}$ & - & - & 一 \\
\hline Without enzyme & 5 & 483 & 10 & 493 \\
\hline Complete mixture & 0.7 & 452 & 38 & 490 \\
\hline Complete mixture & 5 & 320 & 185 & 505 \\
\hline Complete mixture & 60 & 12 & 447 & 459 \\
\hline
\end{tabular}

There was no evidence of any other compounds on the chromatogram except PMP and Pi. The spots were counted on the paper with an end-window counter tube and the results, summarized in Table 8, confirm that no intermediates of low molecular weight other than orthophosphate were formed during the enzymic hydrolysis of PMP.

\section{DISCUSSION}

Three types of enzymes which break down metaphosphate have previously been described. The first type consists of a number of metaphosphatases isolated from various sources, all of which are hydrolytic enzymes which attack only relatively short chain molecules of the size of trimetaphosphate. An example of this type described recently is the enzyme isolated from pea seedlings by Pierpoint (1957); we tested samples of the enzyme which this 
author kindly supplied and found that it did not attack either the bacterial PMP or the synthetic PMP. The second type of polymetaphosphatase attacks long-chain metaphosphates of the molecular size of those isolated from bacteria and moulds as well as the smaller metaphosphates like tri- and hexametaphosphate. Malmgren (1952), working with an enzyme of this type isolated from Aspergillus niger, found that no inorganic phosphate was formed and from the results of kinetic studies has suggested that it can be described as a depolymerase. The third type of metaphosphatase is a transferase described by Kornberg et al. (1956), which in the presence of an unidentified primer transfers terminal orthophosphate from ATP to form high molecular weight PMP. This transferring enzyme is reversible and will split PMP by transferring Pi to form ATP from ADP. The enzyme which we have isolated from Corynebacterium xerosis appears to differ from these three types of metaphosphatases in that it attacks long-chain metaphosphates, with the formation of inorganic orthophosphate; as far as could be detected there was no formation of intermediate short-chain molecules and the enzyme does not attack metaphosphates of shorter chain length than hexametaphosphate. When tested under the conditions described by Kornberg (1957) for transferase activity there was no transfer of phosphate from PMP to ADP or AMP, neither did the addition of ATP or ADP affect the rate of enzyme reaction. The enzyme from $C$. xerosis thus appears to be a hydrolytic enzyme.

The significance of the enzymes which break down metaphosphate in microorganisms must be related to the role which metaphosphate plays in the economy of the organism. Two different views have been expressed recently about this. Russian workers (Belozersky, 1958; Kulaev \& Belozersky, 1957) regard the metaphosphates, because they are energy-rich compounds, as energy stores which can phosphorylate other compounds without the usual intervention of ATP or other nucleotides. In support of this idea it is claimed that metaphosphates are in combination with ribonucleoproteins, and together are concerned with nucleic acid and protein synthesis. In view of the rather drastic isolation procedures involved in the separation of the PMP complexes it is doubtful whether they exist as such in the cell. An alternative suggestion is that PMP may be regarded simply as a source of phosphate. This conception fits with the finding of many laboratories that polymetaphosphates accumulate when cells are given ample phosphate and energy supplies but growth retarded either by nitrogen or other starvation (Winder \& Denneny, 1954; Sall, Mudd \& Davis, 1956). Metaphosphate rapidly disappears from cells once normal growth is started after a period of starvation and the phosphate from PMP appears rapidly in most phosphate fractions of the cell (Mudd et al. 1958; Kulaev \& Belozersky, 1957; Winder \& Denneny, 1957). If, therefore, metaphosphate is regarded as a phosphate store the various metaphosphatases would presumably serve to break down the polymers to orthophosphate.

In connexion with the distribution of the various types of metaphosphatases in micro-organisms it is of significance that we have found an enzyme which splits the polymers to orthophosphate in Corynebacterium xerosis and which does not attack the short-chain molecules, since we found no short-chain 
metaphosphates to be present in the organism. In moulds and yeasts in which the depolymerase type of enzyme occurs, not only do the shorter chain compounds occur but enzymes which split them to orthophosphate have also been isolated.

Activation by EDTA and $\mathbf{M g}^{++}$. In the early experiments $\mathrm{Mg}^{++}$was added to the enzyme assays because of the general finding that $\mathrm{Mg}^{++}$stimulates this type of enzymes (Mattenheimer, 1951; Kornberg, 1957), and a small (20\%) stimulation was found with crude concentrated enzyme preparations; in higher concentrations however, $\mathrm{Mg}^{++}$inhibited even in these crude preparations. With the purified enzyme, $\mathbf{M g}^{++}$did not stimulate and a higher concentration of $\mathbf{M g}^{++}$was markedly inhibitory. All the other metal ions tried were inhibitory. The addition of EDTA to the purified preparation stimulated in low concentration and inhibited in higher concentrations. A mixture of divalent metals did decrease the inhibitory effect of high concentration of EDTA, probably removing its effect by chelation. The inhibitory effect of $\mathrm{Mg}^{++}$and divalent metals might be explained by their combination with the PMP in competition with the enzyme because PMP is a powerful chelating agent. The inhibition by high concentration of EDTA is possibly due to the chelation of activating metal bound to the enzyme.

\section{REFERENCES}

Belozersky, A. N. (1958). Polyphosphates, their formation, and importance for the processes of development of some lower organisms. Proc. IV int. Congr. Biochem. Vienna (in the Press).

Belozersky, A. N. \& Kulaev, I. S. (1957). The polyphosphates and their significance in the development of $A$. niger. Biokhimiya, 22, 29.

Berenblum, I. \& Chain, E. (1938). An improved method for the colorimetric determination of phosphate. Biochem. J. 32, 295.

Berg, G. G. (1958). Ascending chromatography of polyphosphates. Analyt. Chem. 30, 213.

Gornall, A. G., Bardawill, C. S. \& David, M. M. (1949). Determination of the serum proteins by means of biuret reaction. J. biol. Chem. 177, 751 .

Hanes, C. S. \& Isherwood, F. A. (1949). Separation of the phosphoric esters on the filter paper chromatogram. Nature, Lond. 164, 1107.

Hughes, D. E. (1951). A press for disrupting bacteria and other micro-organisms. Brit. J. exp. Path. 32, 97.

Juni, E., Kamen, M. D., Reiner, J. M. \& Speigelman, S. (1948). Turnover and distribution of phosphorus compounds in yeast metabolism. Arch. Biochem. Biophys. 18, 387.

KalCKar, H. M. (1947). Differential spectrophotometry of purine compounds by means of specific enzymes. III. Study of the purine metabolism. J. biol. Chem. 167,461 .

Katchman, B. J. \& Van Wazer, J. R. (1954). The soluble and insoluble polyphosphates of yeast. Biochim. Biophys. Acta, 14, 445.

Kitasato, T. (1928). Über Metaphosphatase. Biochem. Z. 197, 257.

Kornberg, A., Kornberg, S. R. \& Simms, E. S. (1956). Metaphosphate synthesis by an enzyme from E. coli. Biochim. Biophys. Acta, 20, 215.

Kornberg, S. R. (1957). Adenosine triphosphate synthesis from polyphosphate by an enzyme from Escherichia coli. Biochim. Biophys. Acta, 26, 294.

Krishnan, P. S., Damle, S. P. \& BaJaJ, V. (1957). Formation of soluble and insoluble metaphosphates in A. niger. Arch. Biochem. 67, 35. 
Kulaev, I. S. \& Belozersky, A. N. (1957). A study of the physiological role of polyphosphates in the development of $A$. niger using radio-phosphorus ${ }^{32} \mathrm{P}$. Biokhimiya, 22, 587.

Lineweaver, H. \& Burk, D. (1934). The determination of enzyme dissociation constants. J. Amer. chem. Soc. 56, 658.

Mackie, T. J. \& McCartney, J. E. (1945). Handbook of Practical Bacteriology. Edinburgh: E. and S. Livingstone Ltd.

MaLmGren, H. (1952). Enzymatic breakdown of polymetaphosphate: purification and specificity of the enzyme. Acta chem. scand. 6, 16.

MaNN, T. (1944). Isolation of pyrophosphate and metaphosphate from A. niger. Biochem. J. 38, 345.

Mattenheimer, H. (1951). Die enzymatische Aufspaltung anorganischer Poly und Metaphosphate durch organextrakte und Trockenhefe. Biochem. Z. 322, 36.

Mudd, S., Yoshida, A. \& KoIke, M. (1958). Polyphosphate as accumulator of phosphate and energy. J. Bact. 75, 224.

Pfanstiel, R. \& Iler, R. K. (1952). Potassium metaphosphate: molecular weight, viscosity behaviour and rate of hydrolysis of non cross-linked polymer. J. Amer. chem. Soc. 74, 6059.

Pierpoint, W. S. (1957). Phosphatase and metaphosphatase activities of pea extracts. Biochem. J. 65, 67.

Potter, V. R. \& Elvehjem, C. A. (1936). A modified method for the study of tissue oxidations. J. biol. Chem. 114, 495 .

Sall, T., Mudd, S. \& Davis, J. C. (1956). Factors conditioning the appearance and disappearance of metaphosphate in cells of Corynebacterium diphtheria. Arch. Biochem. 60, 130.

Wiame, J. M. (1949). The occurrence and physiological behaviour of two metaphosphate fractions of yeast. J. biol. Chem. 178, 919.

Winder, F. G. \& Denneny, J. M. (1954). Phosphorus metabolism of mycobacteria: determination of phosphorus compounds in some mycobacteria. J.gen. Microbiol. $15,1$.

Winder, F. G. \& Denneny, J. M. (1957). The metabolism of inorganic polyphosphates in mycobacteria. J. gen. Microbiol. 17, 573.

(Received 9 October 1958) 